\title{
WEBINAR: Human rights and democratic regression in Asia
}

Edition 6, 2021

DOI: 10.37839/MAR2652-550X6.19

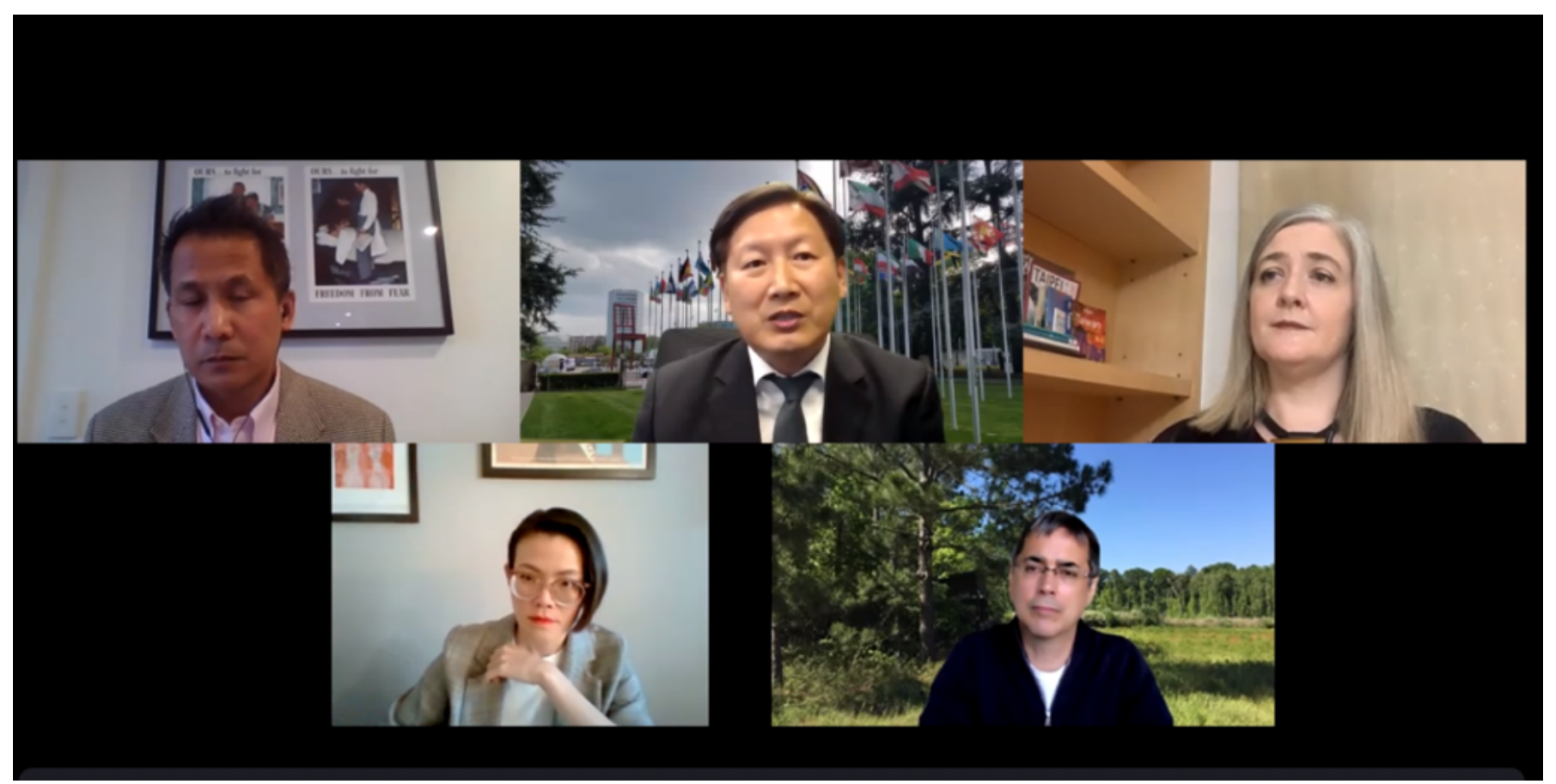

WATCH WEBINAR HERE

Political and social change in Asia since the 1980s has transformed many countries from dictatorships to democracies in a relatively short period of time, further spreading awareness of human rights. Yet, as elsewhere, many societies in Asia have recently witnessed the rapid rise of populists and democratic regression. The struggles faced by human rights activists and the increasingly vocal challenges to a progressive civil society can be seen across the region.

This webinar brings together three experts on human rights and civil society to 
discuss the situation in two countries which have seen recent democratic regression - Thailand and Myanmar - as well as the use of forced disappearances across the region.

It showcases the latest edition of the Melbourne Asia Review on Human Rights and Civil Society in Asia.

\section{Presenters}

Professor Tae-Ung Baik, Chair-Rapporteur, UN Human Rights Council Working Group on Enforced or Involuntary Disappearances.

Dr Janjira Sombatpoonsiri, Assistant Professor, Institute of Asian Studies, Chulalongkorn University.

Dr Jonathan Liljeblad, Senior Lecturer, College of Law, The Australian National University

Chair: Melissa Conley Tyler, Research Associate, Asia Institute, The University of Melbourne.

Introduction: Dr Anthony Spires, Senior Lecturer in Contemporary Chinese Studies, Asia Institute, The University of Melbourne.

\section{Related reading:}

- Professor Tae-Ung Baik. The many challenges of fighting against enforced disappearances in Asia.

- Dr Jonathan Liljeblad. Speaking no truth to power in a time of 
a coup: Myanmar's Human Rights Commission.

- Dr Janjira Sombatpoonsiri. The dark side of civil society? How Thailand's civic networks foster autocracy.

Main image: Protesters use a three finger salute to protest against the government, demand for new constitution and monarchy reform. Bangkok, August 16, 2020. Credit: Adirach Toumlamoon/Shutterstock. 